\title{
nnSEM を用いた潜在変数の因果分析
}

\author{
服部 環 \\ 筑波大学人間総合科学研究科 \\ キーワード : nnSEM, 因果分析, 検定力
}

Causal Analysis of Latent Variables using Non-Normal Structural Equation Modeling

Tamaki HATTORI

Graduate School of Comprehensive Human Sciences, University of Tsukuba

Key words: nnSEM, causal analysis, power of test

構造方程式モデリング（SEM）の利点は変数間の因果 の方向と因果関係の有無を統計的に検討できることにあ るが, 飽和・同值モデルの存在と解の識別不定性により, 分析者が立てた研究仮説を常に検証できるとは限らない。 これは従来の SEM が観測変数の 2 次までの積率を利用す ることによる限界である。しかし，3 次以上の積率を用 いた SEM（Bentler, 1983; 豊田, 2007; Shimizu \& Kano, 2008） は，こうした限界の一部を解決できる可能性がある。例 えば，豊田（2007）は 3 次までの積率を用いた単回帰分析 に焦点を当てたシミュレーション実験により 100 名の標本 で 98\% 以上の確率で因果の方向を特定し, Shimizu \& Kano （2008）は4次までの積率を利用し，100名から200名程度 の標本でほぼ $80 \%$ 程度以上の確率で因果の方向を特定し た。実験結果を過度に一般化することはできないが, 高次 の積率構造を用いた SEM（nnSEM）の有効性が示された。

本稿は 3 つの潜在変数を仮定した双方向モデルにおい て, nnSEM が有意なパス係数を検出するために必要な標 本の大きさをシミュレーション実験により検討する。

\section{方 法}

モデル 3 つの潜在変数をすべて内生変数とする Figure 1 のモデルを想定した。シミュレーション実験では図中のパ 又係数を真值とした。観測変数に対する䛊差 $e_{1}$ から $e_{6}$, 潜 在変数に対する䛊差 $\zeta_{1} \sim \zeta_{3}$ には, 標準化された自由度 8 の $\chi^{2}$ 乱数を用いた。

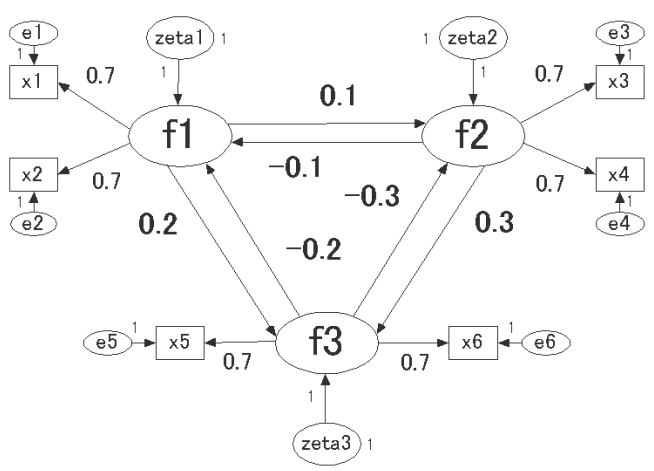

Figure 1 双方向モデルとパス係数の真值

標本の大きさ $500,1000,1500,2000,3000,4000,5000$, 10000 の 8 通りとし, シミュレーションの回数を各条件と も 100 回とした。

母数の推定 構造方程式モデルとして RAM モデル（McArdle \& McDonald, 1984）を用いた。RAM モデルは方程式を

$$
\mathbf{v}=\mathbf{A v}+\mathbf{u}
$$

と表現する。 $\mathbf{v}$ は構造変数を入れたベクトル, $\mathbf{u}$ は外生変 数を入れたベクトル， $\mathrm{A}$ は因子パターンを含むパス係数を 入れた行列である。母数の推定には ADF3（豊田, 2007）を
用いた。ADF3 の適合度関数は

$$
f=(\mathbf{s}-\sigma(\theta))^{\prime} \mathbf{W}^{-1}(\mathbf{s}-\sigma(\theta))
$$

である。ここで, $\mathbf{s}$ は標本から求めた 2 次・3 次の積率を並 べた縦べクトル, $\sigma(\theta)$ は母数の推定值 $\boldsymbol{\theta}$ を用いて計算した 2 次・3 次の積率を並べた縦べクトルである。W は 2 次・ 3 次の積率 ( $\mathbf{s}$ の要素) の漸近分散共分散行列に標本の大 きさ $n$ を乗じた行列である（豊田, 2007）。最適化法として BFGS 法, 計算には R を用いた。母数を推定する際には $\zeta_{1}$, $\zeta_{2}, \zeta_{3}$ の分散を 1 へ固定し，母数の初期推定值の符号を真 值の符号に合わせた。

\section{結果と考察}

各パス係数の推定值の符号が真值の符号と一致し有意水 準 5\%で有意となった割合（一部）を Table 1 に示す。

500 名条件では過半数のパス係数の推定值の符号が真值 と一致し, 有意となった割合は $33 \%$ である。500名では, パス係数の真值が小さいため, 十分な検出力が得られな かった。また， $\hat{\beta}_{31}$ の平均に見られるように推定值のバイ アスがやや大きい。

1000 名条件では過半数のパス係数が条件を満たした割 合は $57 \%$ ，すべてのパス係数が有意となった割合は $13 \%$ で ある。パス係数の真值が小さいため, 1000 名でも十分な検 出力を確保できなかった。小さなパス係数を検出するため には，さらに大きな標本を確保すべきである。

過半数のパス係数が条件を満たした割合は, 1500 名条 件が 77\%, 2000 名条件が $80 \%$ である。したがって，真值 としたような小さなパス係数を検出するためには 1500 名 程度の標本が必要であろう。なお, 一般的な調査研究では 現実的とは言えないが，10000 名の標本があれば，真值の

\begin{tabular}{|c|c|c|c|c|c|}
\hline & \multicolumn{5}{|c|}{ 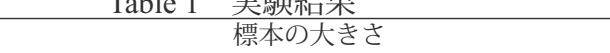 } \\
\hline & 500 & 1000 & 1500 & 2000 & 10000 \\
\hline \multicolumn{6}{|c|}{ 条件を満たしたパス係数の数とその割合 } \\
\hline 0 & 0.04 & 0.02 & 0.01 & 0.01 & 0.00 \\
\hline 1 & 0.06 & 0.03 & 0.00 & 0.01 & 0.00 \\
\hline 2 & 0.41 & 0.19 & 0.07 & 0.06 & 0.00 \\
\hline 3 & 0.16 & 0.19 & 0.15 & 0.12 & 0.00 \\
\hline 4 & 0.19 & 0.37 & 0.39 & 0.31 & 0.07 \\
\hline 5 & 0.12 & 0.07 & 0.20 & 0.22 & 0.04 \\
\hline 6 & 0.02 & 0.13 & 0.18 & 0.27 & 0.89 \\
\hline$\chi^{2}$ の平均 & 53.654 & 53.784 & 52.675 & 51.110 & 50.847 \\
\hline$\chi^{2}$ の分散 & 135.738 & 103.610 & 117.888 & 91.312 & 119.688 \\
\hline$\hat{\beta}_{21}$ の平均 & 0.109 & 0.103 & 0.094 & 0.105 & 0.090 \\
\hline$\hat{\beta}_{31}$ の平均 & 0.266 & 0.203 & 0.221 & 0.183 & 0.196 \\
\hline$\hat{\beta}_{32}$ の平均 & 0.315 & 0.293 & 0.279 & 0.302 & 0.301 \\
\hline$\hat{\beta}_{12}$ の平均 & -0.098 & -0.105 & -0.083 & -0.101 & -0.091 \\
\hline$\hat{\beta}_{13}$ の平均 & -0.239 & -0.196 & -0.202 & -0.183 & -0.194 \\
\hline$\hat{\beta}_{23}$ の平均 & -0.315 & -0.290 & -0.281 & -0.302 & -0.300 \\
\hline
\end{tabular}
ような小さいなパス係数であってもほぼ検出できる。

引用文献

豊田秀樹 (2007). 共分散構造分析［理論編］朝倉書店 